\title{
Suomen monitahoinen possessiivisuffiksi ja suomenoppija
}

\author{
KIRSTI SIITONEN \\ Turun yliopisto
}

\author{
MANAMI MIZUNO
}

Turun yliopisto

Tiivistelmä. Tämä artikkeli käsittelee suomen kielen possessiivisuffiksia opettamisen ja oppimisen kannalta. Äidinkieltään toisena tai vieraana kielenä opettava oivaltaa usein omasta kielestään uusia asioita oppijoiden tulkintojen ja kysymysten kautta. Näin saattaa syntyä myös tarve saada selville, miten äidinkieliset puhujat tosiasiallisesti tulkitsevat omaa kieltään ja käyttävät sitä.

Suomi toisena kielenä -opetuksessa ei possessiivisuffiksi ole keskeisessä asemassa. Possessiivisuffiksiin liittyvät perusasiat esitetään tosin kielioppikirjoissa ja useissa oppikirjoissakin selväpiirteisesti. Oppijat tarvitsisivat kuitenkin lisää tietoa possessiivisuffiksin luonteesta; erityisesti 3. persoonan possessiivisuffiksi viittaamassa elotontarkoitteiseen substantiiviin jää monelle epäselväksi. Asiaproosassa tällainen käyttö on kuitenkin tavallista. Harvoin suomen kielen opiskelijoiden äidinkieli tukee possessiivisuffiksin oppimista. Myös monet suomen kieltä äidinkielenään puhuvat hallitsevat heikosti possessiivisuffiksin moniulotteisen käytön. Puhutun ja kirjoitetun kielen ero hämmentää lisäksi suomenoppijaa.

Kielenoppijan ongelmia possessiivisuffiksin hallinnassa esitellessään kirjoittajat ovat tuekseen halunneet saada selville, millaisissa lauseissa suomea äidinkielenään puhuvat preferoivat possessiivisuffiksin käyttöä ja miten nämä tulkitsevat possessiivisuffiksin viittaussuhteita tekstissä.

Avainsanat: possessiivisuffiksi; suomi toisena kielenä; oppijan äidinkieli; elotontarkoitteinen omistaja; puhekieli ja kirjoitettu kieli 


\section{Johdanto}

Tämän artikkelin kirjoittajista Kirsti Siitonen on opettanut yli 30 vuotta suomea vieraana tai toisena kielenä ja Manami Mizuno on itse aikuisena opiskellut suomea ensin Japanissa vieraana kielenä ja sen jälkeen Suomessa toisena kielenä. Mizunon oma ihmettely possessiivisuffiksin luonteesta innosti hänet laatimaan kyselyn ja kirjoittamaan Suomen kielen ja kulttuurin aineopintojen tieteellisen esseen tästä aiheesta (Mizuno 2006). Essee ja sitä edeltävät keskustelut taas saivat Siitosen katsomaan possessiivisuffiksia uudesta näkökulmasta. Tämän perusteella Siitonen teetti vuonna 2008 ja myöhemmin vuonna 2010 suomenkielisillä suomen kielen opiskelijoilla testin possessiivisuffiksin käytöstä ja tulkinnoista.

Tässä artikkelissa esitellään ensin lyhyesti possessiivisuffiksia ja sen nykykäyttöä. Sen jälkeen selvitetään, miten possessiivisuffiksia opetetaan suomi toisena kielenä -oppikirjoissa, ja tuodaan esille, minkälaisia ongelmia possessiivisuffiksi tuottaa oppijoille. Tässä viitataan sekä oppikirjoihin, oppijoiden äidinkieliin että myös siihen, kuinka suomea äidinkielenään puhuvat suhtautuvat possessiivisuffikseihin ja miten he niitä hallitsevat. Lopuksi pohditaan, minkälaiset opetustavat ja harjoitustehtävät helpottaisivat possessiivisuffiksin oppimista. Esimerkkinä käytetään erityisesti japaninkielisiä oppijoita, koska toinen kirjoittajista on itse japaninkielisenä suomen kieltä opiskeleva.

\section{Possessiivisuffiksi}

Possessiivisuffiksi on yksi suomen kielelle tyypilliseksi koettu ilmiö tai seikka. Sitä ei esiinny indoeurooppalaisissa kielissä, mutta harvinainen se ei ole maailmanlaajuisesti. Melko harvinainen on kuitenkin tapa käyttää persoonapronominin genetiiviä possessiivisuffiksin yhteydessä. (Miestamo 2006: 49.) Iso suomen kielioppi (s. 93-94, tästä lähtien ISK) tulkitsee possessiivisuffiksin taivutusainekseksi. Possessiivisuffiksi on nomineihin ja muihin nominaalisiin muotoihin ja tässä nimenomaan 
lausekkeen edussanaan liittyvä aines, joka ilmaisee persoonaa, esim. minun takkini. Possessiivisuffiksi liittyy useissa tapauksissa infiniittisiin verbinmuotoihin, esim. Tullessani olohuoneeseen kaksi miestä lojui sohvalla. ISK:n nipputunnuksiksi nimeämässä pääteryhmässä possessiivisuffiksit ovat usein välttämätön osa tunnusta. Myös suhteutusadjektiiveihin, esim. minun mittaiseni, ja tilaa ilmaiseviin adverbeihin, esim. Mutisin hämilläni, etten ---, kuuluu possessiivisuffiksi. Adpositioissa possessiivisuffiksi vastaa genetiivisijaista pronominitäydennystä tai liittyy siihen, esim. Kone lensi (meidän) ylitsemme. (ISK: 89, 122-124.) Lauseensisäisen anaforan refleksiivisiin aineksiin kuuluvat possessiivisuffiksilliset itse ja toiset sekä refleksiivinen possessiivisuffiksi. Refleksiiviaineksen tyypillinen korrelaatti on yleisimmin ihmistarkoitteinen, kuitenkin myös elotontarkoitteiset korrelaatit ovat mahdollisia, esim. Osa vaatteista karsiutui pois jo pelkän kokonsa vuoksi. (ISK: 1384, 1389.) Possessiivisuffiksi on laaja-alainen, suomenkielisen tekstin koheesiota monipuolisesti koossa pitävä ilmiö. Pentti Vartiainen (2002) on eritellyt laajassa artikkelissaan kolmannen persoonan possessiivisuffiksin viittaussuhteita, jotka ovat lausekkeen-, lauseen- tai tekstinsisäisiä.

Puhutussa kielessä possessiivisuffiksit jäävät usein pois niin, että pelkkä genetiivimäärite ilmaisee omistajan. Tällä on murrepohjaa pohjalais- ja savolaismurteissa. Possessiivisuffiksien väheneminen puhutussa kielessä on kiihtynyt tutkimusten mukaan kovasti 1900-luvun lopulla. Käyttöön on ilmestynyt myös runsaasti vapaata ja monimuotoista vaihtelua. (ISK: 1241-1242.) Tavallisimpia possessiivisuffiksit ovat puhekielessä 2. persoonassa, esim. Saanks mä lainata sun autoos, ja 3. persoonan tapauksissa, joissa ei ole pronominia genetiivimääritteenä, esim. Tartteeks se ikinä autoosa? (ISK: 124). Jälkimmäisessä esimerkkilauseessa possessiivisuffiksin pois jättäminen muuttaisi jo huomattavasti lauseen merkitystä.

Heikki Paunonen on esitellyt ja pohtinut Virittäjän artikkelissa vuonna 1995 nimenomaan puhesuomen omistusjärjestelmän muuttumista. Hän toteaa, kuinka 1960-luvulta 1990-luvulle muutos on ollut niin dramaattinen, että maallikotkin ovat siihen kiinnittäneet huomiota. 
Toisaalta kirjakielen ja murteiden omistusjärjestelmän periaatteet ovat perinteisesti poikenneet toisistaan, ja toisaalta Paunosen tutkimassa Helsingin puhekielessä possessiivisuffiksit olivat harvinaistuneet 1970luvulta 1990-luvulle selvästi. Verbien nominaalirakenteiden omistusliitteet tuottavat vaikeuksia kokeneillekin kirjoittajille. (Paunonen 1995: $501,505,523,527$.

Eeva Kangasmaa-Minn (1986: 7) ja Valma Yli-Vakkuri (1992: 77-78) ovat tutkineet possessiivisuffiksin käyttöä sekä poisjättämistä ja havainneet, että ilmaukset ovat kyllä puhekielistyneet mutta eivät mielivaltaisesti. Jos esimerkiksi 1. persoonan yhteydessä käytetään possessiivisuffiksitonta tapausta, myös pronominit ovat puhekielisessä asussa mä ja mun. Näin ollen minun takki -kaltaisia sekamuotoja ei esiinny runsaasti. Halusimme tarkistaa, mitä google-hakukone paljastaa nykykäytöstä. Hakukone ei luonnollisestikaan kerro paljoa todellisesta kielenkäytöstä, sama tapaus saattaa tulostua monesta eri kohdasta. Kuitenkin kun vertaillaan pelkästään hakukoneen avulla saatuja tapauksia keskenään, saadaan suuntaa-antavia tuloksia. Etsimme seuraavat ilmaukset: mun edessä (6 880 kpl, 0,46 sek.; 28.11.2008), mun edessäni (618 kpl, 0,25 sek.; 28.11.2008), minun edessä (941 kpl, 0,22 sek.; 20.11.2008), minun edessäni (9 650 kpl, 0,23 sek.; 20.11.2008) ja edessäni (118 000 kpl, 0,10 sek.; $20.11 .2008)^{1}$. Viimeiseen tapaukseen sisältyvät myös minun edessäni -tapaukset. Sekamuodot mun edessäni ja minun edessä ovat ylivoimaisesti harvinaisimpia, ja niukin yleiskielinen edessäni on tavallisin. On otettava huomioon, että kyse on kirjoitetusta kielestä, minun edessäni on ymmärrettävästi siis tavallisempi kuin mun edessä.

Toisaalta Mizuno on huomannut, että suomenkieliset välttävät puhelimen tekstiviesteissään - ilmeisesti merkkejä säästääkseen ja mahdollisesti ei-äidinkieliselle suomenpuhujalle viestiessään - possessiivipronomineja ja suosivat possessiivisuffikseja. 


\section{Possessiivisuffiksi suomi vieraana tai toisena kielenä -oppikirjoissa}

Olemme tarkastelleet eri S2-oppikirjoja. Useissa oppikirjoissa ja kieliopeissa opetetaan hyvin systemaattisesti possessiivisuffiksiin liittyvät perusasiat (ks. esim. Ogishima 1992: 36-38; White 2001: 106-112; BH 2007: 222-225; Karlsson 2009: 141-145). On myös oppikirjoja, joissa ei alkeistasolla ${ }^{2}$ perusteellisesti koota yhteen possessiivisuffiksiin liittyviä seikkoja mutta tekstissä käytetään runsaasti possessiivisuffikseja. Seuraavat esimerkit ovat Suomi2. Minä ja arki -oppikirjan tehtävänannoista: Kerro itsestäsi, lähipiiristäsi ja tunteistasi (TATM: 8), Kirjoita omasta harrastuksestasi (TATM: 58), Kerro harrastuksistasi (TATM: 60) ja Kerro mielipiteesi (TATM: 79).

Tavallisesti oppikirjoissa esitetään myös se, että kirjoitetussa ja puhutussa kielessä possessiivisuffiksin käytössä on runsaasti eroja. Tästä annetaan myös esimerkkejä: sähköpostitekstiä sä olet vieläkin mun paras kamu (TATM: 55) ja puhetta: "mun kaverin kanssa" (TATM: 66). Samojen kirjoittajien keskitasolla oleville oppilaille tarkoitetussa teoksessa Suomi2. Minä ja yhteiskunta $\left(\right.$ TMAT) ${ }^{3}$ opetetaan eksplisiittisesti omistusliitteen käyttöä. Teoksessa sanotaan selvästi, että omistusliite "kuuluu kirjoitettuihin teksteihin” (TMAT: 36), mutta sen lisäksi annetaan esimerkkejä puhutussakin kielessä tyypillisistä omistusliitetapauksista: $A i$, tunnetteko toisenne ja Ootko sä hei ihan tosissas?

Joidenkin oppikirjojen tekstistä ei kuitenkaan käy ilmi, että kyseessä on puhekielinen ilmaus, esim. sinun takana (SW: 84). Virolaisessa aivan uudessa suomen kielen oppikirjassa todetaan, että "suomen kirjakielessä käytetään omistusliitteitä, jotka ovat häviämässä suomen kielestä, mutta toistaiseksi ne kuitenkin vielä vaaditaan norminmukaiseen ilmaisutyyliin” (SK: 81). Toisaalta kirjan tehtävänannoissa on usein ilmaisu: parisi

Esimerkiksi TATM-teos pyrkii opettamaan oppilaita niin, että he vähitellen opiskellessaan siirtyvät eurooppalaisen viitekehyksen mukaan (ks. EV: 47) tasolta A2 tasolle B1 (TATM, opettajan opas: 10).

3 TMAT pyrkii opettamaan oppilaita niin, että he vähitellen opiskellessaan siirtyvät eurooppalaisen viitekehyksen (ks. EV: 47) mukaan tasolta B1 tasolle B2 (TMAT: 3) 
kanssa (esim. SK: 35, 40, 106).Varsinaisen opetustekstin esimerkit on tarkoitettu ääneen luettaviksi, ja niissä ilmaukset ovat suffiksittomia: Mikä sinun puhelinnumero on? Mikä sinun postitoimipaikka on? Mikä sinun ammatti on? jne. (SK: 34.)

Vaikka olemme käyneet läpi varsin runsaasti oppimateriaalia (ks. esim. Ogishima 1992: 36-38; White 2001: 106-112; BH 2007: 222-225; Karlsson 2009: 141-145), emme ole löytäneet ainakaan eksplisiittisiä esimerkkejä, joissa elotontarkoitteisiin sanoihin viitattaisiin possessiivisuffiksilla. Kuitenkin kun suomenoppija alkaa lukea esimerkiksi tieteellistä asiaproosaa, hän kohtaa tämänkaltaisia possessiivisuffikseja melko runsaasti.

Suomen opetuksessa ensimmäiseen possessiivisuffikseja koskevaan mainintaan viittaussuhteet eivät kuulu. Myöhemmin kyllä kiinnitetään huomiota 3. persoonan possessiivisuffiksien esiintymiin, jotka joko viittaavat tai eivät viittaa lauseen subjektiin. Mizunon kokemuksen mukaan opetusta annetaan aiheesta kuitenkin niin vähän ja jollakin lailla ehkä liian varhaisessa vaiheessa niin, että se ei painu mieleen ja siitä aiheutuu myös väärinkäsityksiä. Opetuksessa korostetaan, että possessiivisuffiksi liittyy pronominin jälkeisiin substantiiveihin, ja toisaalta huomautetaan, että suomalaisetkin jättävät possessiivisuffiksin usein pois.

Opiskelun alkuvaiheessa oppijalle selviää tavallisesti lähinnä se, että suomen kielessä on redundantti possessiivisuffiksipääte, joka liitetään persoonapronominin genetiivin jälkeiseen substantiiviin ja jota suomalaisetkaan eivät ainakaan puhutussa kielessä juuri käytä. Se, että ensimmäisen ja toisen persoonan kanssa sekä monikossa että yksikössä kirjoitetussa kielessä käytetään yleensä pelkästään possessiivisuffikseja eikä juurikaan niitä edeltäviä pronomineja, ei välttämättä selviä oppijalle. Lisäksi koko possessiivisuffiksin monipuolinen viittausjärjestelmä jää oppimatta. Myöhemmin se kyllä tulee esille monista teksteistä, mutta opettamatta sen merkitys ja rakenne eivät hahmotu. Erilaisten infinitiivi- ja partisiippirakenteiden yhteydessä tietyt possessiivisuffiksitapaukset opetetaan, mutta opetus saattaa jättää jälkeensä aikamoisen 
hämmennyksen. ${ }^{4}$ On useita oppikirjoja (HM, RT, HS, SW), jotka eivät erityisesti tue possessiivisuffiksien opettamista, ja näin opetuspäätös jää usein opettajan omien ratkaisujen varaan.

\section{Oppijan äidinkieli taustalla vaikuttamassa}

Suomen oppijalle possessiivisuffiksi on jo sinänsä kummallisuus. Voi mennä pitkään niin, että hänelle sattuu jo possessiivisuffiksillisten ilmausten muodostamisessa erehdyksiä. ${ }^{5}$ Oppijalla menee helposti sekaisin, kuka tai mikä on omistettava ja kuka tai mikä taas omistaja ja mihin possessiivisuffiksi liitetään. Monien äidinkielissä on aina kolmatta persoonaa käsiteltäessä näkyvissä myös sukupuoli. Tämänkin tiedon puuttuminen suomen kielestä hämää oppijaa. Oppijalta saattaa saada monentyyppisiä ehdotuksia (ks. taulukko 1) ${ }^{6}$.

Oppija saattaa miettiä, liitetäänkö suffiksi omistettavaan vai omistajaan. Kun oppija on ymmärtänyt, että suffiksi liitetään omistettavaan, hän saattaa miettiä, minkä persoonan mukaan suffiksi valitaan, omistajan vai omistettavan. Helposti oppija ajattelee, että kaikkiin ihmistarkoitteisiin sanoihin liittyvät omistettavat saavat possessiivisuffiksin. Mizunon haastattelemat kuusi japanilaista ja Siitosen opiskelijoina olleet liettualaiset toteavat, että he ainakin erisnimen jäljessä olevaan omistettavaan liittävät possessiivisuffiksin varmuuden vuoksi. Pyrkiessään olemaan mahdollisimman huolellisia ${ }^{7}$ he käyttävät runsaasti possessiivisuffikseja.

4 Erityisesti referatiivirakenteen Mikko uskoo hänen pärjäävän verbimuoto pärjäävän ilman possessiivisuffiksia on ongelmallinen. (Ks. ISK: 532-533.)

$5 \quad$ Myös ensikielenään puhuvalle lapselle possessiivisuffiksin käyttö saattaa poiketa aikuiskielen käytöstä: Nyt hän laittaa päälleen hänen uutensa housunsa --- (tyttö 2 v. 10 kk.); Missä minun villasukatni ovat? (poika 3 v. 6 kk.). (Esimerkit saatu vuonna 2009 eri henkilöiltä.)

6 Esimerkkejä ei ole koottu aineistosta, jonka perusteella voitaisiin esittää frekvenssejä, vaan ne perustuvat Kirsti Siitosen opettajanurallaan tekemiin havaintoihin.

7 Myös suomenkieliset abiturientit ovat tuottaneet ylimääräisiä possessiivisuffikseja pyrkiessään huoliteltuun yleiskieleen ylioppilaskirjoituksissa (ks. Yli-Vakkuri 1992: 78-79). 
таицUкко 1. Possessiivisuffiksillisten ilmausten muodostusongelmia

\begin{tabular}{|l|l|}
\hline Muodostusongelmia & Oppijan kysymyksiä \\
\hline 1) hänensä kirja & Mihin possessiivisuffiksi liitetään? \\
\hline 2) minun miehensä nimi & $\begin{array}{l}\text { Vaikuttaako omistettavan persoona suffiksin } \\
\text { valinnassa? }\end{array}$ \\
\hline $\begin{array}{l}\text { 3) Leenan nimensä } \\
\text { 4) minun mieheni nimensä }\end{array}$ & $\begin{array}{l}\text { Eikö ihmistarkoitteeseen sanaan liittyvä } \\
\text { omistettava saakaan aina possessiivisuffiksia? }\end{array}$ \\
\hline
\end{tabular}

Varmasti oppijat voivat selittää osan valinnoistaan äidinkielensä tai sen kieliopin terminologian perusteella (ks. Siitonen 2003). Äidinkielen vaikutus toisen kielen oppimiseen on ilmeinen; sen vaikutuksen rajoja ja luonnetta ei ole helppo määritellä ilman suuria informanttijoukkoja (ks. Jarvis 2000: 246; Kaivapalu 2005: 26-27). Kaivapalu on laajassa virolaisten ja venäläisten suomenoppijoiden morfologian hallintaa käsittelevässä tutkimuksessaan osoittanut, että erityisesti morfologisesti suomea lähellä olevalla lähdekielellä virolla on morfologista siirtovaikutusta kohdekieleen suomeen (Kaivapalu 2005: 276). Tämä tutkimustulos on toisen kielen oppimisen tutkimuksessa tärkeä löytö (Martin 2007: 76-77) ja antaa viitteitä myös siitä, että possessiivisuffiksitapauksissakin voi esiintyä äidinkielen siirtovaikutusta.

Esittelemme seuraavassa ensin lyhyesti, miten kaksi suomalais-ugrilaista possessiivisuffiksikieltä poikkeaa suomesta. Sen jälkeen annamme muutaman esimerkin Mizunon äidinkielen japanin omistuksen ilmaisemisesta.

Mordvalaiskielessä mokšassa determinatiivisen genetiivin jälkeen tulee possessiivisuffiksi (vrt. kohta 4 taulukossa 1). Jos kyse on proprista (vrt. kohta 3 taulukossa 1), possessiivisuffiksi on myös mahdollinen, joskaan ei pakollinen: Laŕisa Gŕigoŕjevnań ščokava/ščokavanza šud'əśt' śel'məved'anza 'Larisa Grigorjevnan poskia/poskiansa pitkin valuivat kyyneleensä.' (Ks. Bartens 1999: 90.) Lisäksi mokšassa possessiivisuffiksilla merkitään paitsi omistajan persoonaa myös omistettujen lukua: ćorac 'hänen yksi poikansa', ćoranza 'hänen monta poikaansa' (Bartens 1999: 100-101). 
Unkarin kielessä omistusliite ja sijapääte liittyvät sananvartaloon päinvastaisessa järjestyksessä kuin suomessa: unk. utcá $+\boldsymbol{n k}+b a n \sim$ su. $k a d u+l l a+m m e$ (vrt. $\left.{ }^{\star} k a t u m m e l l a\right)$. (Csepregi 1991: 111.) Kun suomessa omistettavan monikollisuus ei tietyissä sijoissa näy ollenkaan (ks. jäljempänä omistettavan homonyymiset muodot suomen kielessä), unkarissa, kuten edellä esitellyssä mokšassakin, omistusliitteen monikon tunnuksesta on nähtävissä, että omistettavia on enemmän kuin yksi: almánk '(yksi) omenamme' almáink '(useammat kuin yksi) omenamme. Monissa sijamuodoissa tosin suomessakin omistettavan useus on nähtävissä mutta ei possessiivisuffiksista vaan sanan monikkovartalosta: su. $k a d u+\boldsymbol{i}+l l a+\boldsymbol{m} \boldsymbol{m} \boldsymbol{e} \sim$ unk. utcá $+\boldsymbol{i}+\boldsymbol{n} \boldsymbol{k}+$ on (ks. Csepregi 1991: 108-111). Unkarin omistusliitettä käytetään yleensä samantapaisesti kuin suomessa. On kuitenkin myös poikkeavia tapoja, joiden perusteella unkarilaisille suomenpuhujille saattaa koitua vaikeuksia. Unkarin vaikutuksesta saattaisi esiintyä seuraavanlaisia ilmauksia: ${ }^{\star}$ Péterin avaimensa. Maaliskuun ${ }^{*}$ viidestoistansa päivä. ${ }^{8}$ (Ks. kohdat 3 ja 4 taulukossa 1.) Edellisen kaltaiset ilmaukset ovat suomen kielessä kielenvastaisia. (Ks. mts. 111-112.)

Useissa kielissä ei ole possessiivisuffiksia, esimerkkinä tästä on japani. Japanissa on persoonapronomineihin liittyvä omistuspartikkeli. (Lampkin 1995: 55-57, 66.) Kun suomen kielen possessiivisuffiksilliset lauseet käännetään japaniksi, niihin on epäselvissä tapauksissa lisättävä persoonapronomini. Näin ollen suomen possessiivisuffiksin opetteleminen alkaa japaninkielisillä, kuten useilla muillakin, aivan itselle tuntemattomasta lähtökohdasta.

Suomenkielinen tekstikatkelma Matilla on kirja. Hänen kirjansa on sininen. Hän antaa sinisen kirjansa äidilleen on japaniksi 'Matti ha hon wo motteimasu. Kare no hon ha aoi desu. Kare ha aoi hon wo okaasan ni agemasu'9. Seuraavassa esitetään, mitä morfeemeja on niissä japaninkielisissä lauseissa, joissa suomen kielessä on possessiivisuffiksi.

Unk. Péter kulcsa. Március tizenötödike (Csepregi 1991: 111-112).

Mizunon käännös. 
(1) [NP Kare [omistuspart. no] [N' hon [subj.part. ha ]]] [A' aoi] [V desu]

Hän- en kirja sininen on

'Hänen kirjansa on sininen'

Ilmauksesta Kare no hon ha 'hänen kirjansa' pystytään sitä edeltävän virkkeen perusteella päättelemään, että Kare 'hän' on Matti. Pronomini ilmaisee omistusta, siksi tarvitaan omistuspartikkeli no. Possessiivisuffiksi ei tarvitse vastinetta; tässä ei suomen puhekielessäkään sitä olisi. Kare no hon -lausekkeen perään tulee subjektipartikkeli ha, koska lauseke toimii subjektina.

(2) [N'Kare [subj.part. ha]] [NP [AP [A' aoi]] [N' hon [obj.part. wo $]]]$ Hän sininen kirja

[N'okaasan äidi- [saajaa ilmaiseva part. ni]]

lle
[V agemasu]

antaa

'Hän antaa sinisen kirjansa äidilleen.'

Edeltävässä virkkeessä on jo todettu, että Matilla on sininen kirja, joten aoi hon 'sininen kirja' -lausekkeeseen ei tarvitse liittää possessiivipronominia kare no. Japaninkielisessä lauseessa ei tarvitse erikseen osoittaa omistajaa, jos tämä on subjekti - tässä kare ha 'hän' Jos sininen kirja ja äiti olisivat jonkun muun kuin lauseen subjektin tarkoitteen, silloin pitäisi mainita niiden omistaja. Jos halutaan täsmentää tai korostaa omistajaa, voidaan kuhunkin sanaan liittää possessiivipronomini tai omistajan erisnimi, mutta mitään kevyempää tapaa ei ole. Toisin sanoen ei ole mitään varsinaisesti possessiivisuffiksia vastaavaa. Lauseessa olevat oliot tai esineet merkitään siis automaattisesti subjektin omistamiksi, jos muuta ei osoiteta.

Edellä olevan perusteella on hyvin ymmärrettävää, että japaninkieliset suomessakin liittävät varmuuden vuoksi persoonapronominin possessiivisuffiksin lisäksi, esimerkiksi lauseisiin Talossani on kolme huonetta. Onko laukkusi punainen? Onko Matti takanani? pronominit minun ja sinun: "Minun talossani on kolme huonetta. Onko sinun 
laukkusi punainen? Onko Matti minun takanani?"10 Japanissa vastaavissa lauseissa ovat pronominit watashi (1. pers. pers.pron.) tai anata (2. pers. pers.pron.) sekä no (omistuspartikkeli).

\section{Oppijan ongelmia}

Kielenoppija, joka opiskelee samaan aikaan sekä suomen kielen substantiivien taivutusta ja erityisesti vartalonmuutoksiin liittyvää astevaihtelua että possessiivisuffiksin liittämistä substantiiveihin, tuottaa helposti kohdekielen vastaisia muotoja: poika, pojan $\rightarrow$ poikansa, ${ }^{*}$ pojansa. Kieltä opettavan on muistettava selvittää, että sanan eri muodot saattavat olla homonyymisiä ja että näin on erityisesti seuraavissa possessiivisuffiksitapauksissa: Hänen poikansa (poika) on pihalla, hänen poikansa (pojan) polkupyörä on pihalla, hän näki pienen poikansa (pojan) ikkunasta, hänen poikansa (pojat) ovat pihalla, hän näki pienet poikansa (pojat) ikkunasta. Konteksti yleensä auttaa korrektiin tulkintaan, joskus (erityisesti määritteiden puuttuessa) kuitenkin teksti itsessään jää moniselitteiseksi.

Kun oppija on käsittänyt asian niin, että possessiivisuffiksi liittyy vain pronomineihin ja sopii myös muihin kuin subjektilausekkeisiin, esim. Hänen talossansa on kaksi huonetta ja keittiö, oppija alkaa harjoitella kolmannen persoonan possessiivisuffiksin variaatiota. Hänelle sanotaan, että suomalaiset käyttävät useammin tietyissä tapauksissa - Vn-suffiksia, joten on parasta oppia kirjoittamaan Hänen talossaan ---. Oppijaa luonnollisesti sekoittaa se, että näiden kahden kolmannen persoonan päätteen välillä ei ole selvää distribuutiota vaan - Vn-tapaukselle on säännöt ${ }^{11}$ ja -nsA-suffiksi käy aina. Kuulostaa varsin epäjohdonmukaiselta, että se, joka periaatteessa käy aina, ei kuitenkaan ole aina suositeltava.

\footnotetext{
10 Näin tekevät monen muunkin kielen puhujat. Suomessahan kirjoituksessa persoonapronomineja käytetään vain painokkaassa asemassa (vrt. White 2001: 115), puheessa taas käytetään pronomineja mutta tällöin possessiivisuffiksi usein jätetään pois.

11 -Vn-suffiksi ei käy nominatiivissa, eikä n:ään loppuvissa sijamuodoissa eikä $A$-vartaloisten sanojen yksikön partitiivissa (ks. ISK: 123).
} 
Jossakin vaiheessa aletaan yksinkertaisin esimerkein opettaa tapauksia, joissa possessiivisuffiksin pitääkin olla yksinään ilman edeltävää genetiivimuotoa: Mies nousi ja otti matkalaukkunsa. Opetuksessa korostetaan, että tässä on kyse nimenomaan miehen omasta matkalaukusta. Jos kyseessä olisi jonkun toisen matkalaukku, olisi syytä sanoa seuraavasti: Mies nousi ja otti hänen matkalaukkunsa. Tätä esimerkkiä valaisemaan ei enää kuitenkaan riitä yksittäinen virke. Edellä pitää olla virke, joka selvittää, kenen matkalaukusta virkkeessä on kysymys. Oppikirjoissa on kyllä esimerkkejä tästä käytännöstä, mutta kun oppija myöhemmin kohtaa monimutkaisempia virkkeitä, hän ei Mizunon kokemusten mukaan enää helposti löydä viittauskohteita.

Mizunon (2006: 10) esseestä12 käykin ilmi, että näistä eri tapauksista kuultuaan oppija ei kuitenkaan aina rohkene jättää pelkkää possessiivisuffiksillista ilmausta tekstiin vaan lisää omasta mielestään selvyyden vuoksi tai jotakin tiettyä henkilöä korostaakseen tekstiin erisnimen tai jonkin muun substantiivin tai sitten pronominin:

(3) Seppo oli Matin kanssa kahvilassa. Tämä odotti siellä Matin vaimo / tämän vaimonsa / hänen vaimoansa (po. vaimoaan).

(4) Seppo jutteli hänen koulutoveriensa (po. koulutoveriensa) kanssa.

Esimerkin (3) tehtävänannossa on täydennettävä lause possessiivisuffiksillisella lausekkeella, johon joskus on liitettävä persoonapronomini, joskus ei. Lauseke ilmaisee, että kyseessä on Matin vaimo. Esimerkin (4) vastaavassa tehtävänannossa lausekkeen on ilmaistava, että kyseessä ovat Sepon koulutoverit.

Virkkeessä, jossa testattavat todennäköisesti tavoittelivat ilmausta "vaimonsa autolla" tai "vaimonsa ystävien", he saattoivat tuottaa ilmauksen vaimon autollaan tai vaimon ystäviensä. (Mizuno 2006.)

Oppijan on vaikea pitää erillään persoonapronomini- ja demonstratiivipronominitapauksia, kuten jo edellä olevista esimerkeistäkin käy ilmi. Erityisen hankalaa se on, jos hän on oivaltanut, että suomessa

12 Esseeseen liittyvässä kyselyssä on 6 japanilaista informanttia. 
voidaan demonstratiivipronomineilla viitata ihmiseen. Erilaisia tapauksia ovat siis seuraavat: hänen kirjansa, mutta sen tassut tai sen kannet ja toisaalta tämän kirja, jossa omistajana on ihminen. On kuitenkin huomattava, että pronomini tämä, samoin kuin myös se ja tuo, voi olla määritteenä possessiivisuffiksilliselle substantiiville, kun kyse ei ole pronominiin tämä liittyvästä omistuksesta, esim. Hän myi ensiksi tämän kirjansa, sitten vasta tuon.

Tähän mennessä kuvattuja seikkoja opiskeltuaan kielenoppija on todennäköisesti ymmärtänyt, että possessiivisuffiksit ovat tärkeä seikka henkilöiden yhteydessä. Kovin paljon opetetun käytännön vastaiselta vaikuttaakin sitten varmasti seuraava ilmaus: Kaupunki myi metsänsä. Lauseessa on kyllä kyse omistamisesta, mutta oletettavasti kielenoppijalla on vaikeuksia ymmärtää, keneen omistajaan viitataan, kun lauseesta ei löydy sen enempää pronominia kuin omistavaa henkilöäkään. Yhä monimutkaisemmaksi ja käsittämättömämmäksi asia käynee, kun abstrakteissakin yhteyksissä tarvitaan possessiivisuffiksia. (Ks. Siitonen 2007: 277.)

\section{Tarvitseeko suomenoppija possessiivisuffiksia suomen kielessään?}

Oppijalla on oppimisen esteenä myös muita esteitä kuin kielensisäiset vaikeudet tai kieltenväliset erot. Nämä esteet ovat osittain kielenulkoisia esteitä. Jo edellä mainittu puhesuomen ja kirjoitetun suomen jyrkkä ero hämää oppijaa. Lisäksi suomenkielisten asenteet possessiivisuffiksin käyttöä kohtaan ja suomenkielisten oma taitamattomuus niiden käytössä saattavat vaikuttaa vieraskieliseen oppijaan. (Vrt. Yli-Vakkuri 1992: 79-82, ja edellä mainittu virolaisen kirjoittama oppikirja, SK: 81.)

Siitonen on opettajanurallaan ja Mizuno suomen kielen opiskelijana usein kohdannut suomalaisia, myös suomen kielen opiskelijoita, joiden mielestä possessiivisuffiksit eivät ole niin kovin välttämättömiä suomen kielessä, että niitä tarvitsisi opettaa kielenoppijoille. Kuitenkin suomalaisten intuitio näyttää tietyissä ilmauksissa kaipaavan possessiivisuffiksia, vaikka possessiivisuffiksi ei näissä sääntöjen mukaan pakollinen 
olisikaan. Siitonen on testannut pienellä suomalaisten suomen kielen opiskelijoiden ryhmällä ( 22 henkeä), millaisissa tapauksissa informantit ensisijaisesti käyttäisivät possessiivisuffiksia, vaikka se ei olisikaan kieliopillisesti pakollinen. Tehtävänanto sisältää jyrkän ilmauksen "oikealla muodolla”. Informantit eivät kuitenkaan ole protestoineet tätä vastaan. Käsittelemme tässä vain osan tehtävän lauseista (koko kyseinen tehtävänanto ks. liite). Oletuksemme mukaisesti kaikki vastaajat käyttävätkin possessiivisuffiksia lauseissa, joissa on tietyntyyppinen ablatiivi-ilmaus, kuten lauseessa Lasi on rakenteeltaan jähmeä esine. Myös elollisen olennon omat ruumiinosat saavat informanteilta possessiivisuffiksin tapauksissa Kissa nuolee tassuaan/tassujaan ja Mari pesee naamaansa joka ilta varmasti 10 minuuttia. Virkkeen Poika oli niin pieni, ettei osannut pitää vielä kynää kädessään täydensi näin possessiivisuffiksillisena 18/22, yksi vastaaja piti possessiivisuffiksitonta ja -suffiksillista muotoa yhtä hyvänä, loput kolme eivät käyttäneet possessiivisuffiksia.

Tehtävän 1 tulosten pohjalta voidaan todeta, että suomen kielessä on tapauksia, joihin ainakin osa suomalaisista ensisijaisesti haluaa liittää possessiivisuffiksin. Vaikka muodoista rakenteeltaan ja kädessään jätettäisiin possessiivisuffiksi pois, lauseiden merkitys ei muuttuisi. Tuskin myöskään kissaa ja Maria koskevissa lauseissa jäisi epäselväksi, minkä tassuista tai kenen naamasta on kysymys, jos possessiivisuffiksi jätettäisiin pois. Mielestämme tämä tehtävä kertoo jotakin possessiivisuffiksin elinvoimasta, kun possessiivisuffiksia ei tehtävänannossa ole edes mainittu.

On tapauksia, joissa possessiivisuffiksi on pakollinen jo sen vuoksi, että possessiivisuffiksi on merkitystä erottava. Tällainen se on eräissä pronominitapauksissa: nimenomaan tapauksessa he puhuivat toisilleen he puhuivat toisille. (ISK: 719-720.) Myös tietyissä konstruktioissa se on pakollinen: tehdäkseen ja olevinaan. Monet muutkin infinitiivi- ja partisiippikonstruktiot (eli lauseenvastikkeet) vaativat possessiivisuffiksia. (Ks. Kangasmaa-Minn 1986: 11-13.) Komitatiivitapauksissakin on käytettävä possessiivisuffiksia. Lause ${ }^{*}$ Hän tuli paikalle kauniine vaimoine ei ole käypä. (ISK: 1211-1212, 1388.) Toisin kuin edellä agenttipartisiippitapauksissa (rakentamani talo) possessiivisuffiksit on teknisesti 
mahdollista korvata persoonapronominin genetiivimuodolla ( ${ }^{*}$ Minun rakentama talo $)^{13}$, samoin postpositiotapauksissa ${ }^{*}$ minun edessä pro edessäni (ISK: 1240-1241).

Suomen kielessä on runsaasti kiteytyneitä taipumattomia ilmauksia, jotka historiallisesti sisältävät kolmannen persoonan possessiivisuffiksin. Suomi toisena kielenä -opetuksessa näitä ei ole tarpeen esitellä, koska tapaukset ovat leksikaalistuneita. Esimerkkejä näistä ovat ainoastaan, enimmäkseen, enintään, tosiaan ja vähintään. (Ks. ISK: 376-378.) Yhä useammin suomenkieliset kielenkäyttäjät ovat kuitenkin alkaneet käyttää kolmannen persoonan possessiivisuffiksia myös sellaisissa adverbeissä, joissa normaalisti possessiivisuffiksia käytetään subjektin mukaan (vrt. Olen huolissaan sinusta, ISK: 377). Suomalaisten itsensä epävarmuus ja epäloogisuus possessiivisuffiksien käytössä tuottanee oppijalle vaikeuksia asian hahmottamisessa.

Tässä alaluvussa esitellyt tapaukset osoittavat, että suomen kielessä on paljon ilmauksia, joissa possessiivisuffiksi on välttämätön eikä edes puhutussa kielessä korvattavissa muilla keinoin. Näin siis oppijakin tarvitsee suomen kielessään possessiivisuffiksia.

\section{Harjoitustehtävien laatiminen ei ole ongelmatonta}

Possessiivisuffiksin ominaispiirteiden opettaminen on haastavaa. Yksiselitteisten tehtävien laatiminen ei välttämättä onnistu. Sekä Siitonen opetuksessaan että Mizuno esseetään varten laatimassaan kyselyssä ovat joutuneet toteamaan, että tehtävään tai testiin tulee helposti laatijan huomaamatta tapauksia, jotka johtavat vastaajan harhaan. Possessiivisuffiksien ja pronominien käyttöä testaavat aukkotehtävät ovat tempustehtävien ohella luontaisesti vielä sellaisia, että jokainen vastaajan ratkaisu vaikuttaa välittömästi seuraavaan ratkaisuun. Näin vastausten tarkastelu ja eri oppilaiden ratkaisujen perusteella annettavat ohjeet saat-

\footnotetext{
13 Viime aikoina suomalaisten opiskelijoiden kirjoituksissa on kuitenkin esiintynyt pikemminkin hyperkorrekteja eli siis virheellisiä tapauksia: opiskelijan ostamansa kirja. (Esimerkki Siitosen suomalaisten opiskelijoiden tekstistä.)
} 
tavat tuntua oppijasta liian monisyisiltä. Tässä esiteltävän aukkotehtävän avulla pyrimme osoittamaan, miten vaikea on saada oppija käyttämään tietynlaista ilmausta, josta voisimme nähdä, hallitseeko hän 3. persoonaan liittyvät kirjoitetun kielen säännöt pronominin käytöstä. Tulkintatehtävän avulla pyrimme tarkastelemaan viittaussuhteiden esittämisen ongelmallisuutta.

Hankalista tehtävistä annamme seuraavan esimerkin (5):

(5) Tehtäväesimerkki 1

Tehtävänanto: Taivuta sulkeissa oleva ilmaus oikeassa sijamuodossa ja lisää siihen possessiivisuffiksi. Korvaa omistajaa ilmaiseva substantiivi tarvittaessa hänen-muodolla.

Isä lähti pyörällä (isän äiti) luokse ja huusi (isän poika), että tämä tulisi perässä. (isän poika) lupasi lähteä tunnin kuluttua.

Ratkaisu 1: Isä lähti pyörällä äitinsä luokse ja huusi pojalleen, että tämä tulisi perässä. Hänen poikansa lupasi lähteä tunnin kuluttua.

Ratkaisu 2: Isä lähti pyörällä äitinsä luokse ja huusi pojalleen, että tämä tulisi perässä. Poika lupasi lähteä tunnin kuluttua.

Tehtävänanto ei välttämättä ole kovin onnistunut. Opettaja yrittää keksiä kokonaisuuden, jossa pitäisi harjoitella kolmannen persoonan omistusilmauksen eroja, mutta loppujen lopuksi tehtävänantoa vastaamaton ratkaisu 2 on idiomaattisempaa suomea kuin tehtävänannonmukainen ratkaisu 1 .

Suomenoppijat yleensä näyttävät Siitosen opetuksessaan saaman tuntuman perusteella onnistuvan aukkotehtävissä suomalaisia yhtenäisemmin. Ehkä näin voisi olla siksi, että heillä ei ole niin paljon omaa kokemusta eikä näkemystä possessiivisuffikseista ja he sen vuoksi luottavat oppimiinsa sääntöihin eivätkä pohjaa ratkaisujaan intuitioon. Opettajalle korjattavaksi ja selitettäväksi aukkotehtävä on ongelmallinen. Ehkä possessiivisuffiksin pitäisi aukkotehtävässä olla vain yksi useista harjoiteltavista seikoista, jottei tehtävään tule possessiivisuffiksien ylikuormitusta.

Olemme halunneet kokeilla, voisiko tulkintatehtävien avulla saada yksiselitteistä tietoa siitä, miten suomen kielen äidinkielinen puhuja 
hahmottaa possessiivisuffikseja ja niihin liittyviä pronomineja. Seuraavassa on kaksi tulkintatehtävää (ks. tehtävät A ja B), jotka annoimme 38 suomalaiselle (22 informanttia, Siitosen kysely 2008; 16 informanttia, Siitosen kysely 2010) tulkittaviksi. Tällaisia tulkintatehtäviä olisi mahdollista käyttää apuna vieraskielisten opetuksessa.

(6) Tehtäväesimerkki 2

Tehtävät A ja B

Tulkitse, keneen mikäkin lihavoitu pronomini tai possessiivisuffiksillinen lauseke kulloinkin viittaa!

A. 1. Seppo oli Matin kanssa kahvilassa.

2. Tämä odotti siellä vaimoaan.

3. Matilla oli mukanaan kaikki vaimonsa matkalaukut, koska tämän piti lähteä kahvilasta välittömästi hänen autollaan pitkälle matkalle ystäviensä kanssa.

B. 1. Seppo oli Matin kanssa kahvilassa.

2. Tämä odotti siellä vaimoaan, joka oli luvannut tuoda hänen autonsa kahvilan eteen.

3. Matilla oli mukanaan kaikki matkalaukkunsa, koska hänen piti lähteä kahvilasta välittömästi autollaan pitkälle matkalle ystäviensä kanssa.

Oletimme, että antamamme tulkintatehtävä on erittäin helppo suomalaisille testattaville ja että he kaikki olisivat tulkinnasta samaa mieltä. Teetimme tehtävän suomalaisille vain ikään kuin todetaksemme, että teksti on yksiselitteinen. Oma tulkintasarjamme isoin kirjaimin ja kaksi poikkeavaa tulkintasarjaa toinen kursiivilla, toinen lihavoinnilla:

(7)

A. 1. Seppo oli Matin kanssa kahvilassa.

2. Tämä odotti siellä (MATTI, Matti, Matti ) vaimoaan. (MATIN VAIMO, Matin vaimo, Matin vaimo)

3. Matilla oli mukanaan kaikki vaimonsa matkalaukut, (MATIN VAIMO, Matin vaimo, Matin vaimo) 
koska tämän piti lähteä kahvilasta välittömästi (MATIN VAIMO, Matin vaimo, Matti)

hänen autollaan pitkälle matkalle (MATIN AUTO, vaimon auto, vaimon auto)

ystäviensä kanssa. (VAIMON YSTÄVÄT, vaimon ystävät, Matin ystävät)

B. 1. Seppo oli Matin kanssa kahvilassa.

2. Tämä odotti siellä (MATTI, Matti, Seppo)

vaimoaan, (MATIN VAIMO, Matin auto, -)

joka oli luvannut tuoda hänen autonsa kahvilan eteen. (MATIN AUTO, Sepon auto, Sepon auto)

3. Matilla oli mukanaan kaikki matkalaukkunsa, (MATIN LAUKUT, Matin laukut, Matin laukut)

koska hänen piti lähteä kahvilasta välittömästi (MATTI, Matti, Matti)

autollaan pitkälle matkalle (MATIN AUTO, Matin auto, Matin auto)

ystäviensä kanssa. (MATIN YSTÄVÄT, Matin ystävät, Matin ystävät)

Yllätykseksemme A-tehtävässä vain 22(/38) vastaajan tulkinta vastaa tarkoin omaa tulkintaamme ja B-tehtävässä 26:n. A-tehtävässä oli lisäksi 4 muuta ja B-tehtävässä 3 muuta keskenään erilaista tulkintaa. A-tehtävässä virkkeessä 2 kaksi on tulkinnut pronominin tämä Sepoksi ja virkkeessä 3 kolme on tulkinnut pronominin tämä Matiksi ja ilmauksessa hänen autollaan peräti 11 on tulkinnut auton vaimon autoksi ilmeisesti ainakin osittain edellä tekemiensä omasta tulkinnastamme poikkeavien tulkintojen vuoksi. B-tehtävässä ongelmana on ollut virkkeen 2 ilmaus hänen autonsa; auton on tulkinnut kaksi informanttia vaimon autoksi ja kolme informanttia Sepon autoksi. Erityisen ongelmallista näyttää olevan siis suomenkielisillekin pronominien tämä ja hän erojen hallinta. Kyseessä lienee siis myös ongelma kolmannessa persoonassa esiintyvien kolmen eri henkilön merkitsemisessä eikä vain possessiivisuffiksin tulkinnassa. Tulkintatehtävät ovat joka tapauksessa hyödyllisiä kielitaitoa tutkittaessa, koska niistä pystyy helposti näkemään vastaajan 
ajatuksenjuoksun. Niistä on havaittavissa, minkälainen tulkintaprosessi on ja missä kohtaa prosessia tapahtuu erehdys tai virhe. Vastaajan ajatuksenjuoksun havainnointi voi myös paljastaa tehtävän laatijalle uusia seikkoja tehtävästä. Koska tulokset eivät suomalaistenkaan osalta ole yhtenäiset, on selvä, että viittaussuhteiden opettaminen vieraskielisille on ongelmallista.

Onkin pohdittava, missä vaiheessa possessiivisuffiksin opettaminen suomi toisena kielenä -kursseilla on järkevintä. Mizuno on todennut, että hyvin varhaisessa vaiheessa eri tapaukset huomioon ottava opetus ei yksinkertaisesti tavoita oppijaa. Toisaalta opetus ei saisi johtaa myöskään harhaan. Hyvin usein oppijalle ei tarpeeksi selvästi osoiteta sitä, että vain silloin, kun possessiivisuffiksillinen sana välittömästi seuraa omistajaa ilmaisevaa pronominia, omistajan pitää olla inhimillinen. Harjoitusten joukossa voisi olla myös sellaisia tunnistustehtäviä, joissa vain yksinkertaisesti on alleviivattava virkkeessä esiintyvät possessiivisuffiksit. Tällaisten tehtävien avulla voitaisiin helposti osoittaa, että elotontarkoitteisiin substantiiveihin voidaan viitata possessiivisuffiksilla: Käräjäoikeudella/ antiikintutkimuksella/maataloudella/kiinteistömarkkinoilla/ ilmastoneuvotteluilla on edessään tai Suomi/hallitus/jäsenvaltiot/yhtiö --- tavoittee$n a a n^{14}$. Koska autenttisissa teksteissä kuitenkin esiintyy melko paljon possessiivisuffiksia, opetusta pitää Mizunonkin mielestä antaa varhain mutta sitä pitää jatkaa eri opiskeluvaiheissa taidon karttuessa.

Selväpiirteiset, yksinkertaiset tehtävät auttavat oppijaa hahmottamaan possessiivisuffiksien merkitystä ja roolia suomen kielessä. Eila Hämäläisen jo vuosia sitten ilmestyneen harjoituskirjan (HE: 14-19) possessiivisuffiksiharjoitukset luovat hyvän pohjan oppimiselle. Tehtävätyyppi, jossa oppijan on passiivisesti tunnistettava tekstin possessiivisuffiksit, saattaa olla joskus opettavaisempi kuin possessiivisuffiksien tuottaminen. Hämäläisen tehtävässä 8 (mts. 18-19) yhdistyvät onnistuneesti tunnistus- ja tuottamistehtävä, kun siinä on muunnettava koko teksti niin, että yksikön 1. persoonan ja siihen liittyvien possessiivisuffiksien sijasta käytetään yksikön 3. persoonaa. Aivan tuoreessa Salli-Marja

14 Google-hakukone, viitattu 1.2.2010 (hakusanoina edessä̈̈n ja tavoitteenaan). 
Bessonoffin ja Eila Hämäläisen harjoituskirjassa (BH 2009: 232-237) on paljon onnistuneita possessiivisuffiksiharjoituksia. Mukana on muunnostehtäviä persoonasta toiseen tai puhekielestä kirjakieleen, aukkotehtäviä, yksi selitystehtävä ja tehtävä, jossa pitää miettiä, milloin 3. persoonassa possessiivisuffiksi yksinään, milloin substantiivin genetiivi ilman possessiivisuffiksia ja milloin taas persoonapronominin genetiivi possessiivisuffiksin kanssa olisi välttämätön. Näissäkin harjoituksissa kuitenkin omistettava aina suhteutetaan inhimilliseen omistajaan. Vuonna 2009 ilmestyneessä Suomi2. Minä ja yhteiskunta -teoksessa on onnistunut tehtävä, jossa possessiivisuffiksi ensiksikin pitää tunnistaa ja sen lisäksi on pystyttävä yhdistämään tunnistetut possessiivisuffiksit niiden käyttöä kuvaaviin sääntöihin (TMAT: 36).

\section{Lopuksi}

Possessiivisuffiksi on kaiken kaikkiaan hyvin monitahoinen ilmiö, ja sen hallinta näyttää olevan nykysuomalaisellekin paikoin hankalaa. Vieraskieliselle on ilman possessiivisuffiksin tuntemusta suomenkielisten tekstien lukeminen kuitenkin erittäin vaikeata - erityisesti kolmannen persoonan - $V n$-loppu ilman pronominia ei avaudu kaikille lukijoille possessiivisuffiksiksi, ja siksi tekstin tulkinta jää hyvin hämäräksi, jos tätä ei osaa.

Idea persoonapronominin mahdollisesta puuttumisesta ja pelkän possessiivisuffiksin esiintymisestä on opittava suomen kielestä käsin. Toki jokaisen oma kielikin ilmaisee jollakin tavoin omistamista ja selvittää tiettyjä subjekti- ja objekti- sekä omistussuhteita erilaisilla viittauksilla ja oletuksilla, ehkä myös määräisyyden kautta, mutta kuitenkin useimmiten toisin keinoin kuin suomessa.

Suomenkielisen asiaproosan lukeminen vaatii possessiivisuffiksien hyvää hallintaa ja toisaalta, jos ei-äidinkielinen suomenpuhuja joutuu kirjoittamaan opinnäytteitä tai muuta asiatekstiä suomeksi, possessiivisuffiksikin on osattava. Erityisen tärkeätä abstraktimmissa tekstilajeissa on ymmärtää, että possessiivisuffiksi voi viitata elotontarkoitteiseen 
substantiiviin. Kuten olemme todenneet, vieraskielisille tarkoitetuissa kieliopeissa eikä oppikirjoissa tätä ei oppijalle erityisesti osoiteta.

\section{Lähteet}

Bartens, Raija 1999. Mordvalaiskielten rakenne ja kehitys. Suomalais-Ugrilaisen Seuran toimituksia 232. Helsinki: Suomalais-ugrilainen Seura.

BH 2007 = Bessonoff, Salli-Marja, Eila Hämäläinen 2007. Tilanteesta toiseen.

A Finnish Course. Helsinki: Helsingin yliopisto.

BH 2009 = Bessonoff, Salli-Marja, Eila Hämäläinen 2009. Tilanteesta toiseen. Har-

joituksia/Exercises. Helsinki: Helsingin yliopisto.

Csepregi, Márta 1991. Unkarin kielioppi. Helsinki: Finn Lectura.

$\mathrm{EV}$ = Eurooppalainen viitekehys. Kielten oppimisen, opettamisen ja arvioinnin yhteinen eurooppalainen viitekehys 2004. Helsinki: WSOY.

HE = Hämäläinen, Eila 1982. Suomen harjoituksia 2. Suomalaisen Kirjallisuuden

Seuran toimituksia 381. Helsinki: Suomalaisen Kirjallisuuden Seura.

HM = Heikkilä, Satu, Pirkko Majakangas 2007. Hyvin menee! Suomea aikuisille. 6. painos. Helsinki: Otava.

HS = Hart, Susanna 2008. Suomea paremmin. 2. painos. Helsinki: Finn Lectura. ISK = Hakulinen, Auli, Marja Vilkuna, Riitta Korhonen, Vesa Koivisto, Tarja Riitta Heinonen, Irja Alho 2004. Iso suomen kielioppi. Suomalaisen Kirjallisuuden Seuran toimituksia 950. Helsinki: Suomalaisen Kirjallisuuden Seura.

Jarvis, Scott 2000. Methodological Rigor in the Study of Transfer: Identifying L1 Influence in the Interlanguage Lexicon.- Language Learning 50, 2, 245309. doi:10.1111/0023-8333.00118

Kaivapalu, Annekatrin 2005. Lähdekieli kielenoppimisen apuna. Jyväskylä Studies in Humanities 44. Jyväskylä: Jyväskylän yliopisto.

Kangasmaa-Minn, Eva 1986. Possessiivisuffiksin apologia. - Sananjalka 28, 7-16.

Karlsson, Fred 2009. Suomen peruskielioppi. 4., laajennettu ja uudistettu painos. Suomalaisen Kirjallisuuden Seuran toimituksia 378. Helsinki: Suomalaisen Kirjallisuuden Seura.

Lampkin, Rita L. 1995. Japanese Verbs and Essentials of Grammar. Passport Books. Illinois: Lincolnwood.

Martin, Maisa 2007. A square peg into a round hole. Fifteen years of research into Finnish as a second language. - Nordand. Nordisk tidsskrift for andrespråksforskning. Årgang 2, 1, 63-85. 
Miestamo, Matti 2006. Suomi maailman kielten joukossa eli mikä suomen rakenteessa onkaan erityistä? - Minna Harmanen, Mari Siiroinen (Toim.). Kielioppi koulussa. ÄOL:n vuosikirja XLX. Helsinki: ÄOL, 43-54.

Mizuno, Manami 2006. Suomen kielen kolmannen persoonan omistusliitteen käyttö. Tieteellinen raportti ja essee. Suomen kieli ja kulttuuri ulkomaalaisille. Turun yliopisto.

Paunonen, Heikki 1995. Puhesuomen muuttuva omistusmuotojärjestelmä. Virittäjä 99, 501-531.

RT = Rinne, Päivi, Tiia Tempakka 2005. Opettajan ideareppu. Kommunikatiivisia harjoituksia suomen tunnille. Helsinki: Finn Lectura.

Siitonen, Kirsti 2003. Kieliopin terminologia tuottamassa ongelmia suomi toisena kielenä -opetuksessa. - Pirkko Muikku-Werner, Hannu Remes (Toim.). VIRSU: Viro ja suomi: kohdekielet kontrastissa. Lähivertailuja 13. Joensuu: Joensuun yliopisto, 81-87.

Siitonen, Kirsti 2007. Suomen kielen ominaispiirteitä. - Kaarina Merenluoto, Arja Virta, Pia Carpelan (Toim.). Opettajankoulutuksen muuttuvat rakenteet. Ainedidaktiikan symposium 9.2.2007. Turun yliopiston kasvatustieteiden tiedekunnan julkaisuja B:77. Turku: Turun yliopisto, 273-280.

SK = Sark, Kaare 2009. Hyvä-parempi-paras. Soome keele õppekomplekt algajaile. Tallinn: Iduleht.

SW = Silfverberg, Leena, Leila White 2006. Supisuomea. 2. painos. Helsinki: Finn Lectura.

TATM = Tukia, Kaisa, Eija Aalto, Peppi Taalas, Sanna Mustonen 2008. Suomi2. Minä ja arki. 1.-2. painos. Helsinki: Otava.

TATM, opettajan opas = Tukia, Kaisa, Eija Aalto, Peppi Taalas, Sanna Mustonen 2007. Suomi2. Minä ja arki. Opettajan opas. Helsinki: Otava.

TMAT = Tukia, Kaisa, Eija Aalto, Peppi Taalas, Sanna Mustonen 2009. Suomi2. Minä ja yhteiskunta. Helsinki: Otava.

Vartiainen, Pentti 2002. Kolmannen persoonan possessiivisuffiksin viittaussuhteet suomen yleiskielessä. - Sananjalka 44, 7-58.

White, Leila 200. Suomen kielioppia ulkomaalaisille. 4. uudistettu painos. Helsinki: Finn Lectura.

Yli-Vakkuri, Valma 1992. Suomen kielen omistusliitteen tulevaisuus. Prognoosi vuosien 1991 ja 1992 ylioppilaskirjoitusten äidinkielen kokeen pohjalta. Sananjalka 34, 77-87. 


\section{Liite}

Täydennä aukko sulkeisiin laitetun sanan oikealla muodolla.

1. Olet tuossa asussa (ulkonäkö) niin pelottava, että lapset juoksevat varmasti pakoon.

2. Perussanat ovat (vartalo) yksimorfeemisia, jakamattomia lekseemejä.

3. Lasi on (rakenne) jähmeä esine.

4. Nämä huonekalut on poistettu (käyttö)

5. Suojakotelo on (väri) tyylikkään valkoinen.

6. Poika oli niin pieni, ettei osannut pitää vielä kynää (käsi)

7. Kyllä (puhe) kuulee, että Maija on Helsingistä.

8. Kissa nuolee (tassu)

9. Mari pesee (naama) joka ilta varmasti 10 minuuttia.

\section{Kirsti Siitonen}

Suomen kieli

Fl-20014 Turun yliopisto, Finland

kisiito@utu.fi

\section{Manami Mizuno}

Yo-kylä 8 D 10

FI-20540 Turku, Finland

manmiz@utu.fi 


\section{Many-sided possessive suffix of Finnish and a Finnish learner}

\author{
KIRSTI SIITONEN \\ University of Turku
}

\author{
MANAMI MIZUNO \\ University of Turku
}

Those who are teaching their mother tongue as a second language often learn things from their own language thanks to the interpretations and questions put forward by their students. This may shift their attention to the issue of how do native speaker in fact interpret and use their language.

The present article is concerned with the Finnish possessive suffix from the point of view of teaching and learning. First, this suffix and its present-day use are shortly studied. Then, it will be clarified how this suffix is taught in the textbooks of Finnish as a second language, and which difficulties the suffix presents to the learners. The mother tongues of the learners are referred, and the question is raised of how do Finnish native speakers grasp these suffixes. Finally, the question is raised, how to enhance the learning of possessive suffixes by teaching and exercises.

The possessive suffix is not in a central role in the Finnish as a second language teaching, although its basic rules are presented in the textbooks. However, learners need more information on the nature of possessive suffix; this concerns especially the $3^{\text {rd }}$ person possessive suffix in the case that it refers to a substantive that designates something non-living. In standard grammars or textbooks for foreigners this is usually not demonstrated to the learners. In the abstract and scientific prose, such expressions are customary, though.

The authors have tried to find out, in which kinds of sentences Finnish native speakers prefer the use of possessive suffix and how they interpret the reference relations of the suffix in various texts.

It is seldom that learners' mother tongue helps them in their efforts to learn the Finnish possessive suffix. Moreover, learners of Finnish are puzzled by the difference between colloquial and written language.

Keywords: possessive suffix; source language; non-living reference; Finnish as a second language; colloquial Finnish; written standard Finnish 